\title{
Credit Risk Transfer, INFORMED MARKETS, AND SECURITIZATION
}

\author{
Susan M. Wachter
}

\section{OVERVIEW}

- Mortgage-backed securities (MBS) fueled the U.S. housing bubble that led to the financial crisis of 2007-09. Moreover, the pricing of these securities failed to expose the growing credit risk in U.S. mortgage markets.

- Recently, the governmentsponsored enterprises Fannie Mae and Freddie Mac, which guarantee most U.S. MBS, developed credit risk transfers (CRTs) as a means of shifting some mortgage credit risk to the private sector.

- The author describes the reasons why MBS failed to price risk, and argues that properly structured securitization markets, such as the market for CRTs, could be used to appropriately price and reveal credit risk, thereby limiting real estate bubbles and reducing systemic risk in housing markets.

- To succeed in this regard, CRT markets must be transparent-by providing full information on the underlying mortgages and by standardizing mortgages, potentially through the use of a common securitization platform. In addition, CRTs must trade with open pricing in liquid markets, and avoid counterparty risks and incentives to underprice credit.
A cross countries and over time, credit expansions have - led to episodes of real estate boom and bust. ${ }^{1}$ Ten years ago, the global financial crisis, the most recent bust, began with the Panic of 2007. ${ }^{2}$ The pricing of mortgage-backed securities (MBS) had given no indication of rising credit risk, nor had market indicators such as rates of early payment default or delinquency (that is, defaults and delinquencies in a mortgage loan's first year). Higher house prices had masked the growing underlying credit risk. Myopic lenders, who believed that house prices would continue to increase, had underpriced credit risk. ${ }^{3}$

In the aftermath of the crisis, Congress, under the Dodd-Frank Act, put into place a new financial regulatory architecture that included both increased capital requirements and stress tests, in an effort to limit the banking sector's role in amplifying real estate price bubbles in the future (Duca, Popoyan, and Wachter, forthcoming; Calem, Correa, and Lee 2016). However, a major piece of unfinished business remains: reform of the U.S. housing finance system, whose failure was central to the crisis. Fannie Mae and Freddie Mac, the government-sponsored enterprises (GSEs) that were put into conservatorship under

Susan M. Wachter is the Albert Sussman Professor of Real Estate and a professor of finance at The Wharton School, University of Pennsylvania.Email: wachter@wharton.upenn.edu.

The views expressed in this article are those of the author and do not necessarily reflect the position of the Federal Reserve Bank of New York or the Federal Reserve System. To view the author's disclosure statement, visit https://www.newyorkfed.org/research/ epr/2018/epr_2018_crt-informed-markets_wachter. 
Securitization's Share of the U.S. Mortgage Market in the 2000s

\begin{tabular}{|c|c|c|c|c|c|c|c|c|c|}
\hline & 2000 & 2001 & 2002 & 2003 & 2004 & 2005 & 2006 & 2007 & 2008 \\
\hline Total originations & 1,048 & 2,215 & 2,885 & 3,945 & 2,920 & 3,120 & 2,980 & 2,430 & 1,485 \\
\hline Total securitized & 615 & 1,355 & 1,857 & 2,716 & 1,882 & 2,156 & 2,045 & 1,864 & 1,264 \\
\hline $\begin{array}{l}\text { Percentage of originations } \\
\text { securitized }\end{array}$ & $59 \%$ & $61 \%$ & $64 \%$ & $69 \%$ & $64 \%$ & $69 \%$ & $69 \%$ & $77 \%$ & $85 \%$ \\
\hline Private-label securities & 136 & 267 & 413 & 586 & 864 & 1,191 & 1,145 & 707 & 58 \\
\hline $\begin{array}{l}\text { Private-label as a percentage } \\
\text { of total originations }\end{array}$ & $13 \%$ & $12 \%$ & $14 \%$ & $15 \%$ & $30 \%$ & $38 \%$ & $38 \%$ & $29 \%$ & $4 \%$ \\
\hline $\begin{array}{l}\text { GSE securities as a percentage } \\
\text { of total originations }\end{array}$ & $46 \%$ & $49 \%$ & $50 \%$ & $54 \%$ & $35 \%$ & $31 \%$ & $30 \%$ & $48 \%$ & $81 \%$ \\
\hline
\end{tabular}

Source: Inside Mortgage Finance.

the Housing and Economic Recovery Act (HERA) of 2008, ${ }^{4}$ await a mandate for a new securitization structure. The future state of the housing finance system in the United States is still not resolved.

Currently, U.S. taxpayers back almost all securitized mortgages, through the GSEs and Ginnie Mae (together known as the "agencies"). ${ }^{5}$ While private-label securitization (PLS) securitization by non-agency financial institutions-had provided a significant share of funding for mortgages before the crisis, since 2007 PLS has withdrawn from the market (McCoy and Wachter 2017), as shown in the table above.

The appropriate pricing of MBS can discourage lending if risk rises and, potentially, can limit housing bubbles that are enabled by excess credit. However, securitization markets-including the over-the-counter market for residential MBS (RMBS) and the ABX subprime mortgage-backed securities index, described in detail in Section 2-failed to price increasing risk in the housing bubble years 2003-07.

With the goal of bringing private-market discipline to bear on risk taking in securitized lending, the GSEs have recently developed credit risk transfers (CRTs) to trade and price credit risk. For such a goal to be achieved, however, CRT markets must avoid the failures that occurred with the use of financial assets to price risk in the global financial crisis. Are the prerequisites for such an approach in place? Moreover, how will CRTs fare under alternative scenarios of housing finance reform?

Section 1 of this article describes the fundamental problem of nontransparent securitization, which resulted in the mispriced credit that contributed to the housing price bubble. Section 2 shows how the structure of securitization markets worsened this problem. Section 3 compares CRTs with the securities markets that failed and examines GSE reform proposals to determine how they undermine or support the potential benefits of CRT trading. Conclusions are presented in Section 4. 


\section{RMBS Mispricing, THE LACK OF Transparency, AND NAÏVE INVESTORS}

While securities trading can price risk, it failed to do so in the run-up to the crisis. In order to draw lessons for CRT markets as part of the reform of the housing finance system, it is necessary to understand why housing finance markets failed to price risk. Herring and Wachter $(1999,2003)$ show how housing finance ratifies and amplifies housing bubbles. Owing to the heterogeneity of housing, lenders use "comparables," based on current market values, to decide loan amounts, a circumstance that creates a positive feedback loop between increases in house prices and expansions of lending (Wachter 2016).

Housing markets are prone to bubbles. Because of high transaction costs and inelastic supply, housing prices adjust slowly to changes in fundamentals (Glaeser, Gyourko, and Saiz 2008; Aastveit and Anundsen 2017) and are path-dependent and predictable (Case and Shiller 1989). Backward-looking price expectations result in buyers offering higher prices in markets where prices have increased after positive shocks. Optimistic buyers, subject to "bubble thinking," drive real estate prices up, even when prices exceed fundamental values. ${ }^{6}$ Unlike in other asset markets, short-sellers do not counter optimistic buyers. Even if homeowners recognize a bubble forming, they cannot short-sell homes into the bubble and buy their specific homes back at the bust, which is the short-sell exercise that works for commodity and financial asset markets to help keep bubbles in check. In this way, real estate markets are "incomplete."7

Optimistic buyers affect market pricing when they have access to credit; without borrowed funding, buyers would soon be out of money. ${ }^{8}$ The availability of lending at rates that underprice credit risk enables bubbles to build, whether financed on bank portfolios or through securitization. ${ }^{9}$ Securitization provided the funding in the U.S. housing bubble. While the GSEs and Ginnie Mae had provided securitization of long-term mortgages since the savings and loan debacle of the 1980s, in the run-up to this crisis, the structure of securitization changed.

Securitization was not new, but the explosion of private-label MBS was new and different than the traditional GSE-based securitization, especially when it came to the risks involved. As long as GSE securitization dominated the mortgage market, credit risk was kept in check through underwriting standards, and there was not much of a market for nonprime, nonconforming, conventional loans. Beginning in the 1990s, however, a new, un-regulated form of securitization began to displace the standardized GSE securitization. This private-label securitization (PLS) was supported by a new class of specialized mortgage lenders and securitization sponsors.... [The] PLS created a market for nonprime, nonconforming conventional loans. (Mian and Sufi 2015, p. 97) ${ }^{10}$

Without enforced standards, "originate-to-distribute" lenders competed for fees by offering easier lending terms (Wachter 2014). With lowered lending constraints, borrowing expanded both to new (previously unqualified) borrowers and to existing borrowers who could now borrow more, including both homeowners and house flippers (Lee, Mayer, and Tracy 2012; Albanesi, De Giorgi, and Nosal 2017). As a result, housing demand and prices increased beyond levels justified by long-term fundamentals. ${ }^{11}$ 
CHART 1

Regression Coefficients on FICO Score and Loan-to-Value Ratio by Vintage
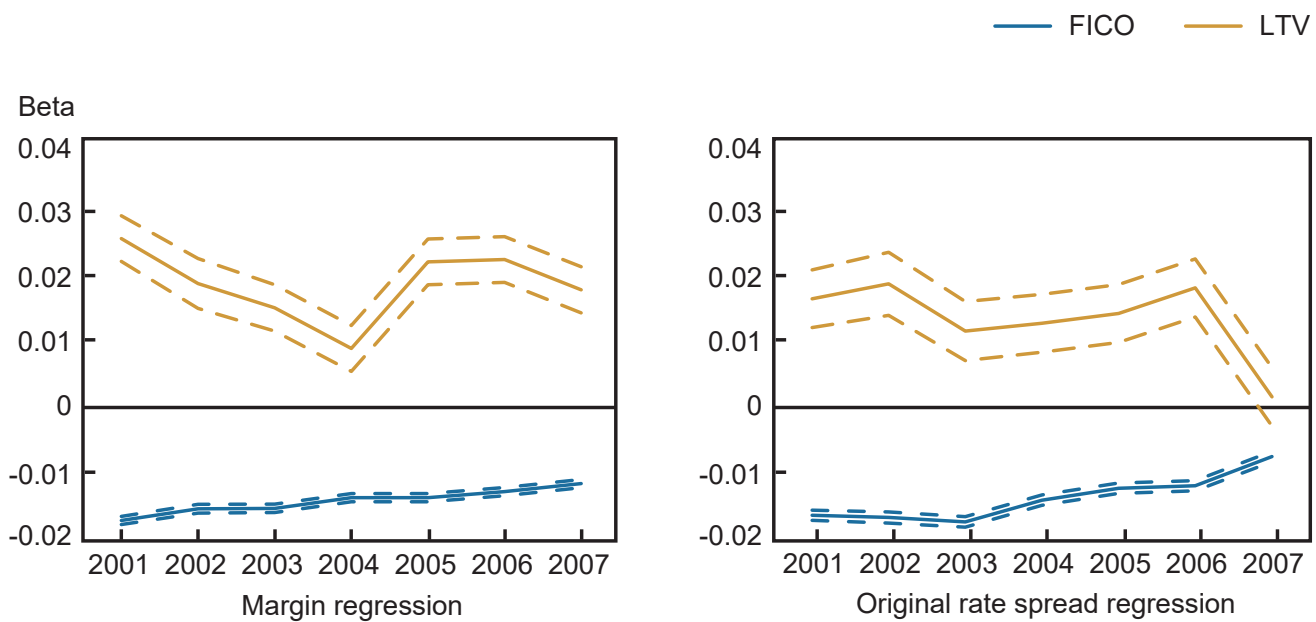

Source: Levitin, Lin, and Wachter (forthcoming).

Notes: The dependent variables are margin and original interest rate spread, measured in percentage points. The beta reflects the response of the dependent variable to a one-unit change in FICO score or LTV ratio, all else equal. The dashed bands represent 95 percent confidence intervals.

The price of credit risk, as identified by RMBS data, did not increase with the explosion of credit. As seen in Charts 1 and 2, which are based on loan-level data from a major bank that served as trustee for PLS, adjusted for observable characteristics, the risk premium (gross margin and initial rate spread) did not rise over the years 2001-06, and the coefficients of loan-to-value (LTV) ratios remained relatively constant while FICO scores decreased (Levitin, Lin, and Wachter, forthcoming).

The easing of credit constraints and the underpricing of credit risk on mortgage loans led both to higher housing prices (Pavlov and Wachter 2011), reinforced by backward-looking expectations and, in a positive feedback loop, to further increases in credit supply. By the beginning of 2006, as the demand of previously constrained borrowers became satisfied, the pace of increases in housing demand slowed and house prices leveled out; in April 2006, as interest rates rose, prices began to fall (Chart 3). In 2007, with prices flattening in some markets and declining in others, the capitalization of expected future house price gains into current prices could not hold; price declines accelerated and financial firms providing nontraditional mortgages faltered as investors and rating agencies questioned their viability. ${ }^{12}$ The Panic of 2007 began in July when rating agencies announced that they could no longer provide ratings for RMBS, and redemptions of bank-sponsored funds from BNP Paribas, which, along with other European banks, had invested heavily in U.S. RMBS, were suspended.

By 2008, the implosion of mortgage firms, which were shut out of capital markets, prevented risky borrowers from refinancing to cover existing loans-leading to defaults, further declines in housing prices, construction halts, and increased financial distress among lenders. The 2008-09 economic downturn resulted in increased unemployment and a massive rise in 


\section{Chart 2}

Regression Coefficients on Vintage Year
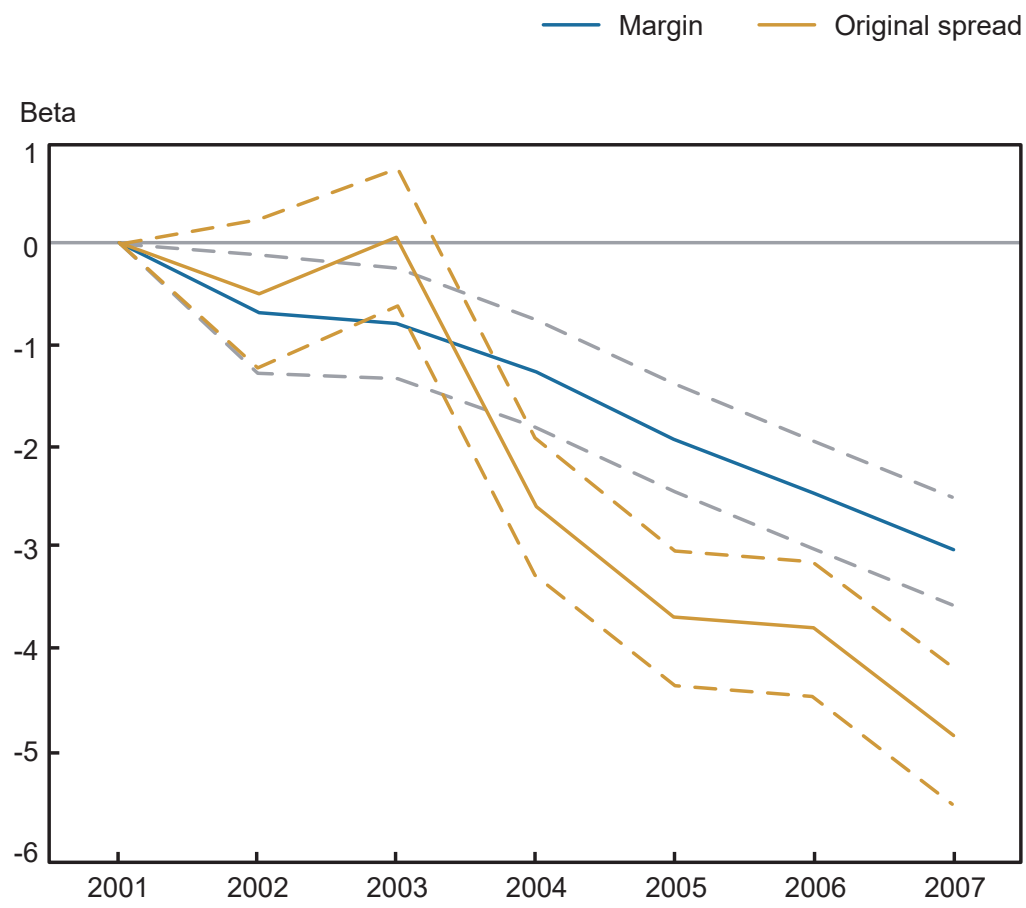

Source: Levitin, Lin, and Wachter (forthcoming).

Notes: Coefficients take into account the time-varying effects of FICO score and loan-to-value ratio, and are normalized to zero at 2001. Margin and original interest rate spread are measured in percentage points. The dashed bands represent 95 percent confidence intervals.

foreclosures as unemployed borrowers could not pay back or, given price declines, refinance their mortgages. With foreclosures and increased supply on the market, housing prices fell further and more financial firms failed. A self-reinforcing downward spiral was in place.

The yields on RMBS, along with the underlying mortgage yields, had failed to identify the growing risk. "Investor tapes" (according to U.S. Court of Appeals for the 2nd District, 2017) included invalid and unverifiable data: Debt-to-income ratios were not verified, and combined loan-to-value (CLTV) ratios were not available (Levitin and Wachter 2012, 2015). The lack of data on loan terms, the multiplicity of instruments, and the complexity of loan underwriting terms made it difficult to track the aggregate credit risk related to loan terms and borrower characteristics.

Moreover, PLS traded infrequently and over the counter and were marked to "model" rather than to market, and given the lack of standardization, no widely reported measure of risk premiums existed (Davidson, Levin, and Wachter 2014). The structural complexity of the private-label mortgage securitization system-which encompassed not only mortgages securitized as MBS but also MBS securitized as collateralized debt obligations (CDOs), CDOs securitized as CDO, and the inclusion of credit default swaps (CDS) in CDO contracts-made 
Chart 3

The Residential Real-Estate Bubble

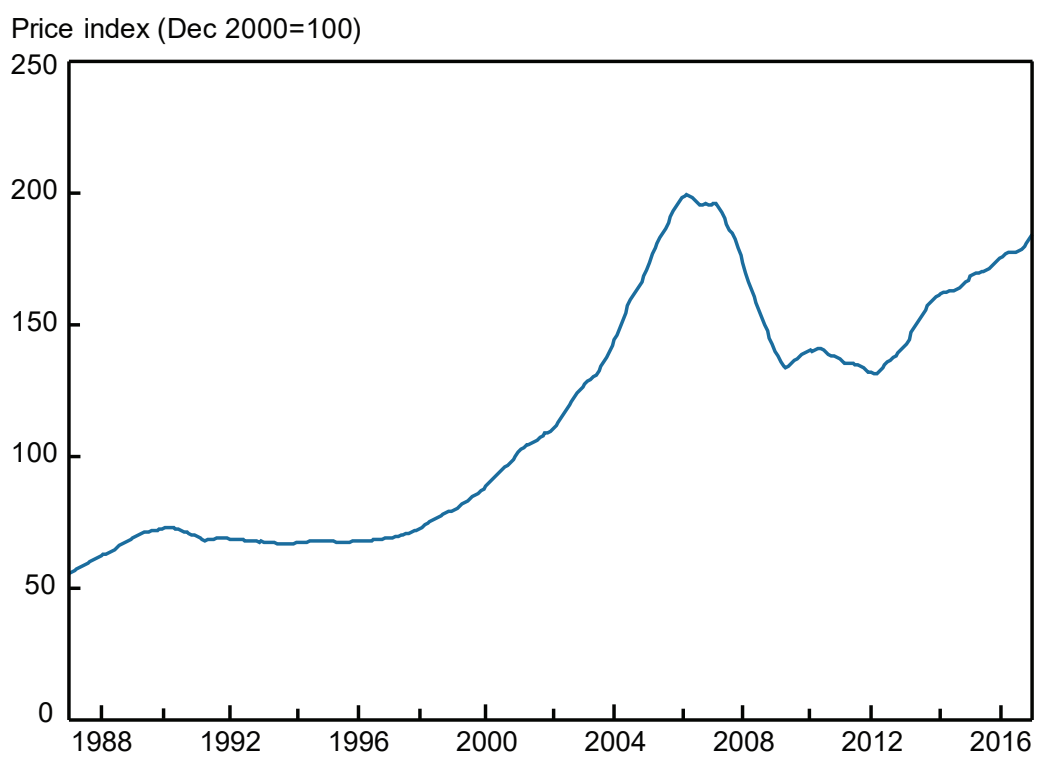

Source: Levitin and Wachter (2012).

monitoring counterparty risk difficult (Cordell, Huang, and Williams 2011). The packaging of risky $\mathrm{BBB}$ tranches of RMBS into CDOs led to more risky credit, rated as AAA and held in asset-backed securities (Agarwal et al. 2010). The lack of transparency on credit expansion enabled market participants to ignore growing risk, as long as housing prices continued to rise. For naïve investors, the supply of private-label RMBS and CDOs satisfied a global demand for highly rated and apparently safe U.S. dollar-denominated debt (Pavlov and Wachter 2011).

Through the bubble years, the aggregate debt of households increased relative to GDP, as did the debt of financial firms (see Chart 4). Overall household debt to GDP more than doubled (from 44 percent to 91 percent, with the increase composed entirely of mortgage debt since consumer debt had decreased with credit consolidation), as housing prices relative to fundamentals exploded. Naïve investors in RMBS, however, would not have looked to these readily available simple aggregates to evaluate the underlying collateral default risk in housing markets. Financial firms (McCoy, Pavlov, and Wachter 2008) also leveraged up to provide these loans (unlike corporations or the federal government, whose debt ratios to GDP remained constant over these years, as also shown in Chart 4) and were exposed to warehouse risk - the risk of rates rising during the funding period between the disbursal of funds to mortgage borrowers and the securitization of the loans-as they packaged RMBS into CDOs, increasingly insured against default risk by credit default swaps. 
Chart 4

Sectoral Contribution of U.S. Gross Debt as a Percentage of GDP
Nonfinancial
Financial
Household and nonprofit
Government

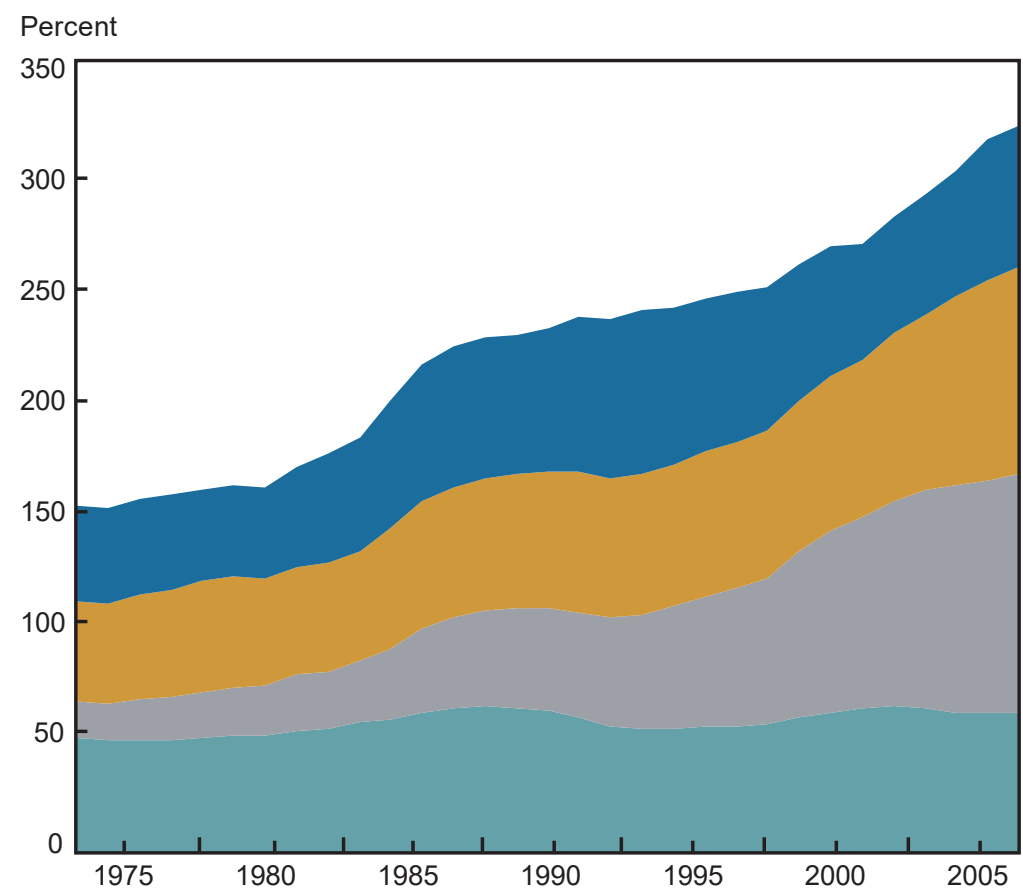

Source: Federal Reserve Board, "Financial Accounts of the United States," Z.1 table.

\section{CDS Mispricing and Market Structure}

CDS issuance skyrocketed over the 2002-07 period, with the years 2005-07 witnessing a tenfold increase in the issuance of CDS on mortgage-backed securities (Bank for International Settlements 2013). Contrary to the standard intuition, CDS premiums were insensitive to the underlying mortgage credit quality. Loans packaged in MBS that had CDS available substantially underperformed other securitized loans (Arentsen et al. 2015). Not only were the financial institutions that were providing CDS taking on more risk at lower premiums, they were apparently doing so with less screening than was being undertaken by securitizers. They were also expanding the share of RMBS insured by CDS. Arentsen et al. document that CDS as a share of RMBS issued increased until, by 2006, CDS insured more than 50 percent of RMBS. As described earlier, the failure of RMBS to price growing risk may reflect naïve investors, reliant on ratings; it may also reflect the growing use of CDS, which seemingly de-risked RMBS. However, these factors do not explain CDS pricing, since, in this case, sellers were often large international financial firms. ${ }^{13}$ 
In determining their provision or pricing of CDS, competitive insurance (guarantor) firms, like naïve investors, might not look to aggregate measures such as the rise in debt-to-GDP ratios or the rise in the price of housing relative to income and rents (or adjust for the declining cost of homeownership owing to lower interest rates and backward-looking expectations). Rather, competitive firms might rely on the available characteristics of the mortgages they are insuring (FICO score and LTV) and the expected (rating-firm estimated) losses on these mortgages, as well as their issuance costs relative to market insurance premiums (fees), to determine CDS pricing. Like bank lenders and naïve investors, these firms might take housing prices as given without factoring in growing aggregate lending risk (Wachter 2014).

Most guarantor firms, however, were large and clearly exposed to growing risk. Managers of these firms would have been aware of the growth of the CDS market and aggregate credit, and the increasing correlated risks. Yet the actions of these large firms did not account for increasing risk. Pavlov, Schwartz, and Wachter (2017) rationalize this using a risk-shifting argument. In this model, a financial institution generates positive profits from its intermediation business and is capable of issuing CDS without a regulatory requirement of actuarially fair reserves. The optimal credit default swap premium that such a financial institution requires in order to assume the default risk of fixed-income instruments is a function of the institution's capital (reserves) and current exposure. Hence, institutions generally require an increasing premium to assume additional risk. ${ }^{14}$ However, if the financial institution already has a large CDS exposure and is undercapitalized, further issuance comes at a lower premium. ${ }^{15}$ An undercapitalized institution that already has substantial default risk exposure would engage in risk shifting (to purchasers of CDS, who are now exposed to counterparty risk) and assume more risk at lower rates to gain the short-term fees associated with the issuance of CDS.

Effectively, once a firm receives a negative signal about the value of the underlying mortgages, the firm issues more CDS at a lower premium, making cheap financing easily available. In other words, the presence of a financial institution with large default risk exposure in the market reduces the premium required to insure additional risk. Therefore, negative signals about the default risk of the debt instruments increase the quantity of insured instruments but do not increase the default insurance premium. ${ }^{16}$

This risk-shifting mechanism is consistent with the stylized facts observed in the crisis, including the explosive growth in CDS and the constant risk premiums on the underlying RMBS. It is also consistent with the stable pricing of an index introduced to trade CDS, at least through mid-2007. In January 2006, Markit Group, in collaboration with a group of major banks, launched the ABX.HE (the ABX), linked to the pricing of twenty specific home equity RMBS deals, including some of the largest deals during this period. The overall index incorporated a basket of indexes, differentiated by credit risk rating.

At the outset, the purpose of the $\mathrm{ABX}$ was to create transparency in the otherwise opaque over-the-counter market for credit risk (described earlier), with daily updates on pricing. The $\mathrm{ABX}$ would provide a forum for market-based price discovery of mortgage credit risk, allowing market participants, insurers, and supervisory authorities to identify and price the aggregate risk profile of the market.

The pricing of CDS, despite the daily updates and growing volume, was notably constant, as shown in Chart 5; until the collapse of the CDS providers, prices persisted unchanged from issuance value. While pricing had become transparent, the underlying characteristics and risk profile of the mortgage book of business had not, nor had the growing counterparty 
Chart 5

ABX Index from 2006 to 2009

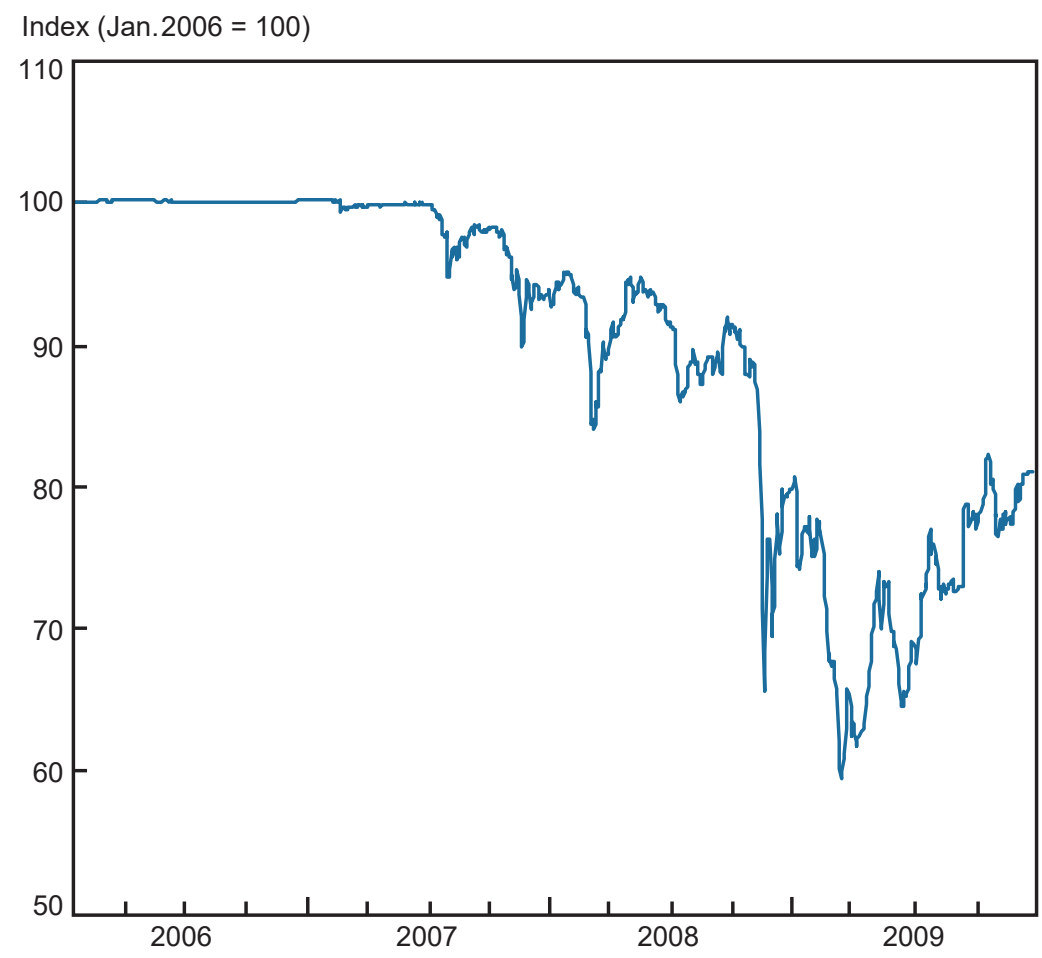

Sources: Markit Group; Bloomberg L.P.

Notes: The chart shows prices for the ABX.HE.AAA.06-1 index from January 19, 2006, to December 31, 2009, with the initial value set to 100. A smaller (bigger) index implies widening (tightening) spread.

risk. The issuers of CDS had an incentive to increase the supply of insurance, which resulted in a lower price of insurance. The greater the risk of price declines and a future credit collapse, the greater the incentive to increase efforts to provide credit and receive fees.

Short-sellers like hedge fund manager Bill Ackman did eventually succeed in putting sufficient downward pressure on CDS providers to expose the counterparty risk, but the harm was done. ${ }^{17}$ With the ensuing collapse of CDS providers, ABX pricing deteriorated quickly. Financial markets then used the $\mathrm{ABX}$ as a valuation and accounting standard to write down CDS and RMBS holdings. Because the ABX was the only source of market-based pricing, major CDS dealers relied on it to account for losses. The ABX did bring market pressures to bear on the pricing of RMBS, albeit in the aftermath of the crisis. After August 2007, CDS pricing identified an increase in systemic risk (Giglio 2010), although as Stanton and Wallace (2011) observe, the ABX indexes were minimally correlated with the actual performance of the RMBS to which they were linked, since they priced in the fear and uncertainty associated with the crisis. 
Would market-based price discovery and the trading of similar financial derivative instruments, such as credit risk transfers, have prevented the build-up of risk and kept the crisis from occurring in the first place? Or would the presence of naïve investors and financial institutions (with misperceived fortress capital ${ }^{18}$ ) that write insurance no matter what have prevented risk from being appropriately priced?

\section{Credit Risk Transfers and the Restructuring of the GOVERNMENT-SPONSORED ENTERPRISES}

As the financial crisis unfolded, the U.S. government put the GSEs Fannie Mae and Freddie Mac into conservatorship, under HERA. Amid falling housing prices, the solvency of the GSEs was in question because of the correlated risks created by the credit expansion, the GSEs' expanded guarantees (particularly of the 2007 book of business), and their purchase of private-label MBS for portfolio investment (Frame et al. 2015). The conservatorship of Fannie Mae and Freddie Mac, together with the securitization of Federal Housing Administration (FHA) loans by Ginnie Mae, meant that the credit risk of almost all mortgages securitized in the United States had now become the responsibility of the U.S. taxpayer. ${ }^{19}$

In response to this exposure, the Federal Housing Finance Agency (the GSEs' regulatory overseer) in 2012 called for the use of credit risk transfer programs as a means to offload some of that credit risk to the private sector. Fannie Mae and Freddie Mac now each allocate risk to private investors through CRT vehicles, predominantly Connecticut Avenue Securities (CAS) and Structured Agency Credit Risk (STACR), respectively (Federal Housing Finance Agency 2017). Fannie Mae and Freddie Mac issue CRTs as unsecured debt obligations whose returns are tied to underlying reference loan pools, with payments determined by loan performance and repayments of the underlying reference pools. Chart 6 shows the credit spread at issuance of the M2 (lower-rated mezzanine tranche) of the CAS security and its tightening over time relative to the credit default swap index (Federal Housing Finance Agency 2017).

The structuring of CRTs enables markets to trade and price credit risk and interest rate risk separately. Borrowers must ultimately pay for both. The affordable pricing of long-term fixed-rate mortgages, in particular, requires the efficient pricing of credit and interest rate risks. ${ }^{20}$ With no taxpayer or government exposure, investors price and bear interest rate (and prepayment) risk through an efficient so-called TBA (to be announced) market. (The TBA market is the market in which agency securities trade. In a TBA trade, the seller of MBS agrees to a sale price but does not specify which securities will be delivered to the buyer on settlement.) $)^{21}$ This setup requires standard mortgages for which relevant information (such as date and interest rate) is available, so that it is possible to estimate interest rate risk. But it excludes other individual loan information, because this information would fragment the pool into separate securities and thus decrease liquidity. The efficient pricing of interest rate and prepayment risks is central to the delivery of housing finance for long-term fixed-rate mortgages. ${ }^{22}$ CRTs do not interfere with the TBA market given that CRT returns are separately determined based on the portfolio performance of already issued RMBS.

The private-label RMBS market conflated interest rate and credit risk, making distinct pricing of each difficult. ${ }^{23}$ The question is whether the CRT market can, similarly to the TBA 
CHART 6

Fannie Mae CAS Credit Spread at Issuance versus BBB Corporate Bond Index
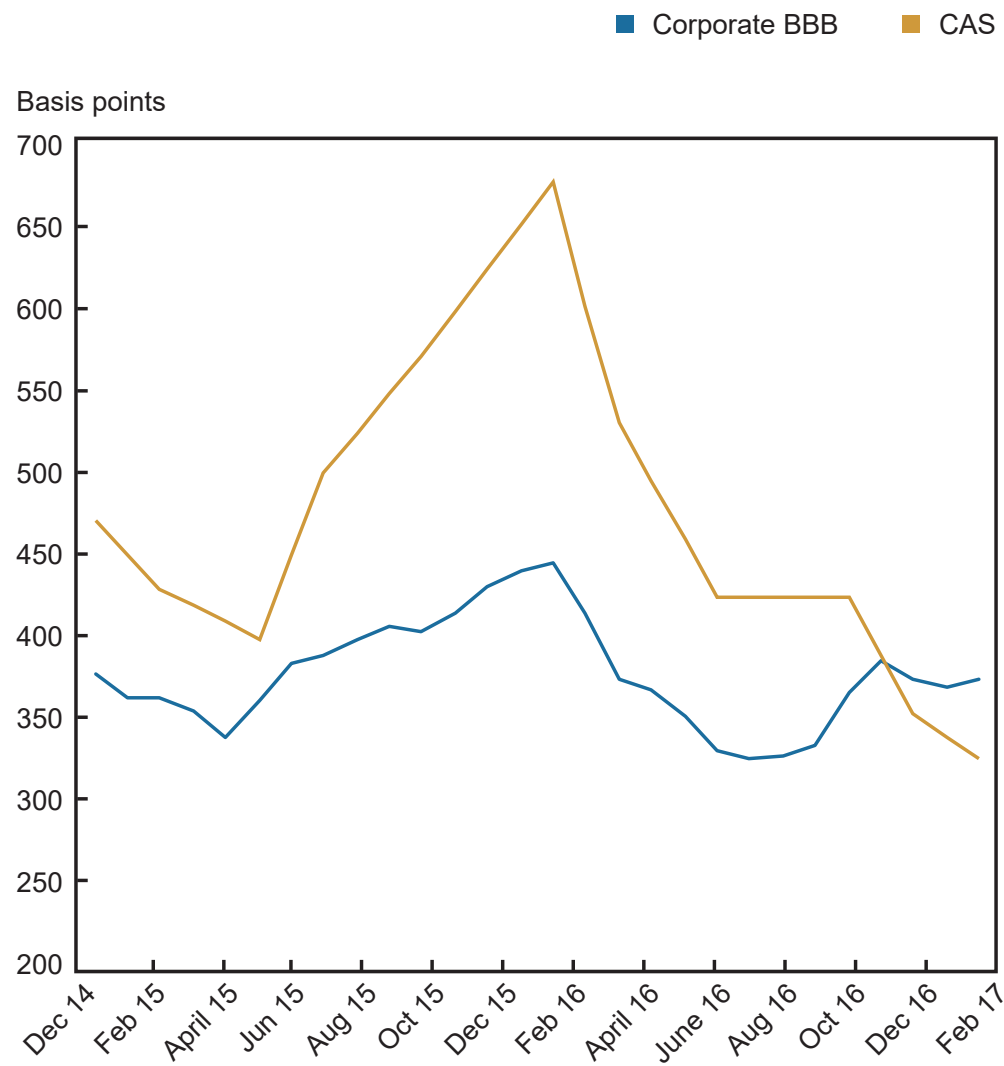

Sources: Connecticut Avenue Securities (CAS) data is from Bloomberg L.P. The BBB corporate bond index is the Bank of America Merrill Lynch U.S. Corporate BBB Effective Yield index from the Federal Reserve Bank of St. Louis FRED database.

Note: The chart shows the credit spread at issuance of the M2 (lower-rated mezzanine tranche) of the CAS security and its tightening over time relative to the credit default swap index.

market, price and take on credit risk efficiently. The answer to that question is likely to depend on the securitization and regulatory structures put in place by GSE reform.

The trading of CRTs currently provides information about what private capital markets would charge for the credit risk generated by the credit guarantee business of the GSEs (in addition to sharing that risk). CRTs' relationship to the default risk of the underlying mortgages is clear, with the credit losses borne by CRTs being tied to specific portfolios of GSE loans whose characteristics are known, tracked, and available to investors, an important contrast to the earlier PLS.

As a result, CRT pricing helps identify market perceptions of the risk of mortgage lending based on the GSEs' portfolios. This, too, is in contrast to the lack of a traded security to enable 
price discovery, at least until the ABX was in place. The market-implied pricing of CRTs, when compared with the GSEs' pricing of credit risk through the GSEs' guarantee fees, can indicate whether the GSEs' pricing of credit risk is in line with the market's perception of risk. Several entities, notably the American Enterprise Institute and the Urban Institute, now provide information on mortgage market risk that could help inform pricing of CRTs based on the characteristics of securitized credit. ${ }^{24}$ Such an assessment is possible because the characteristics of the underlying securitized credit are standardized and transparent. The CRTs' assured payout avoids counterparty risk and incentives to underprice CDS (Wachter 2017).

Going forward, the restructuring of the GSEs will interact with the functioning of CRT markets. GSE reform proposals differ on the structure of securitization markets and, specifically, on whether there should be one, a few, or multiple guarantors. In other dimensions, proposals have coalesced on elements of what is necessary for a securitization market to succeed (McCoy and Wachter 2017). There is, for example, agreement across proposals about the need for TBA markets to have a role in the efficient pricing of interest rate risk. Two proposals explicitly call for mandatory CRTs and others call for their use to some degree, as described below. There is also agreement regarding private capital (in some form) being in a first-loss position to absorb downturns in the MBS market in order to limit taxpayer losses, as well as for the use of a common securitization platform (CSP) to provide enhanced transparency. Major disagreements exist regarding the structure of the guarantor market, specifically, as noted, on the number of guarantors and on the oversight of credit pricing by regulators. The lessons of the recent crisis show that these differences may matter for the functioning of the CRT market.

One plan (Parrott et al. 2016) proposes the creation of a regulated government corporation, tentatively named the National Mortgage Reinsurance Corporation (NMRC), that would combine Fannie Mae and Freddie Mac. Although the authors of the proposal envision the NMRC as free from the profit-driven or market-share-driven motives inherent in a stock corporation, they contemplate private investment in NMRC as consisting of common equity of 3.5 percent and preferred equity of the same percentage. The NMRC would perform the same core functions as the GSEs - to buy and pool loans, issue MBS, and oversee master servicing activities. A second plan, developed by Andrew Davidson (2016) and based on earlier proposals from researchers at the Federal Reserve Bank of New York (Mosser, Tracy, and Wright 2016), calls for the formation of one or more mutual companies that would replicate the functions of today's GSEs and the functions of the otherwise similar NMRC proposal. The third, the Milken Institute proposal (De Marco and Bright 2016), puts forth Ginnie Mae as the basis for the CSP and calls for multiple guarantors. A fourth proposal, from the Mortgage Bankers Association (2017), has come out in favor of multiple guarantors as well, with all guarantors using the CSP, under a government guarantee. Finally, a fifth, from Moelis and Company (2017), offers a plan that would essentially reform the existing two entities along current lines, but with private capital restored.

The eventual structure of the GSEs will influence how well the CRT market works or even whether the market can work at all. With multiple guarantors, it would be difficult to maintain a robust CRT market as well as a TBA market (Kanojia and Grant 2016), simply because liquidity declines with multiple issuers. This problem would worsen if firms could choose their portfolio composition, the lending terms and risks, and the guarantee fees associated with the mortgages they underwrite. If multiple firms offer their own CRT programs that are geographically concentrated and there is an income shock to their geographic area, an outflow of capital is 
likely to occur, which would lead to a reinforcing downward price spiral given the path dependency of housing prices (Pavlov, Wachter, and Zevelev 2016). While guarantee fees might signal such risk, the path dependency of prices would reinforce the withdrawal of funding to riskier markets. Riskier markets would also experience a disproportionate widening of risk premiums, with a national slowdown of growth. Guarantors would have to raise their guarantee fees at a time of regional market or national distress, leading to self-reinforcing decreases in house prices and declines in credit provision.

One way to avoid this outcome is by requiring tight regulation of multiple firms on mortgage criteria and requiring the same mortgage guarantee fees and lending rates (given mortgage terms and characteristics) reflecting the characteristics of the pooled portfolios of the firms, much as Ginnie Mae functions today through the FHA's enforcement of mortgage terms across all issuers. This option could indeed work, and the CRT market could price credit risk in the overall book of business, consistent with the proposals that put forth more than a few guarantors. With the regulatory setting of standardized lending rates and guarantee fee pricing, multiple guarantors could issue CRTs referenced to the marketwide book of business, with the market pricing of CRTs providing feedback to regulators about credit risk.

In this regulatory setup, guarantee fees are determined either at the discretion of regulators or in a nondiscretionary way, with guarantee fees linked to CRT pricing. Currently, GSEs have discretion in issuing CRTs and linking CRT pricing to the setting of guarantee fees. Restructuring, as called for in several of the reform proposals, with CRT pricing automatically linked to mortgage interest rates, may reintroduce instability into markets. As demonstrated by ABX pricing after the crisis, periods of market uncertainty translate into illiquid markets. Increases in the cost of credit affect housing prices and credit flows in turn, leading to reinforcing downward spirals. Reform proposals suggest circuit breakers to limit this destabilizing effect. The proposal from Parrott et al. (2016) states that, in the case of interest rates increasing beyond a certain point, the NMRC should hold guarantee fees constant thereafter. ${ }^{25}$ However, having the government guarantee mortgage rates as risk increases in an effort to limit housing price declines would help private-sector holders of CRTs and would increase taxpayers' risk exposure. Alternatively, as described earlier, it is possible to conjure a scenario in which the discretionary underpricing of credit by one or a few (or many) guarantors for the purpose of increasing market share or short-term fees destabilizes markets in the long term. With few or many guarantors, naïve investors, and path-dependent housing prices, a role for macroprudential supervisory oversight of housing finance markets, informed by credit risk trading, remains.

\section{Conclusion}

The global financial crisis began a decade ago. During the crisis, many private sector financial institutions failed or were bailed out, and the U.S. government put the GSEs Fannie Mae and Freddie Mac into conservatorship under the Housing and Economic Recovery Act of 2008. Historically and across countries, real estate markets have been subject to bubbles, which have resulted in financial busts; in the recent crisis, mortgage-backed securitization shrouded growing credit risk and amplified the real estate bubble. Going forward, well-structured securitization markets, such as the credit risk transfers established by the GSEs, can price and reveal credit risk. 
One requirement for avoiding the pitfalls of the past mispricing of credit risk is transparency. This requirement is met through the full provision of information on the mortgages in the GSE portfolios referenced by CRTs (along with information on portfolio lending and other mortgage funding sources). Standardization - as is currently provided by the predominance of the GSEs and Ginnie Mae-allows the tracking of aggregate credit risk and, going forward, would potentially be enabled by the common securitization platform. As a second requirement, credit risk instruments need to trade with open pricing in liquid markets, unlike in the crisis, when credit risk instruments traded over the counter. This, too, is in place. Third, the market needs to avoid counterparty risk and incentives to underprice credit. In the CRT markets' current constitution, this is not a concern.

Nonetheless, the future structure of the GSEs will affect whether CRT markets can work to limit credit risk. CRTs issued by multiple guarantors may not be liquid, and their pricing in times of distress may destabilize markets.

CRT markets, if appropriately structured, can signal a heightened likelihood of systemic risk. Capital markets failed to do this in the run-up to the financial crisis owing to misaligned incentives and shrouded information. With sufficiently informed and appropriately structured markets, CRTs can provide market-based discovery of the pricing of risk and, with appropriate regulatory and guarantor response, can advance the stability of mortgage finance markets. 


\section{Notes}

\footnotetext{
${ }^{1}$ Herring and Wachter (1999).

${ }^{2}$ Cordell, Huang, and Williams (2011).

${ }^{3}$ Pavlov and Wachter (2009).
}

${ }^{4}$ See Frame et al. (2015) for a description of the process of conservatorship and its limitations.

${ }^{5}$ This does not take into account the credit risk covered by private mortgage insurance, which offers an alternative way to bring private capital into a risk-taking position ahead of the taxpayer.

${ }^{6}$ See Hendershott and Slemrod (1982) and Poterba (1984). Gallin (2008) shows that deviations between prices and rents have predictive power for future price changes.

${ }^{7}$ See Jeske, Krueger, and Mitman (2013) for a discussion of housing as an incomplete market.

${ }^{8}$ Herring and Wachter (1999) show how portfolio gains owing to price increases cause lenders to believe that they have more than sufficient capital and encourage them to lend more, with shocks and price declines then leading to bank decapitalization, sudden halts to lending, and reinforcing price declines. See Bernanke, Gertler, and Gilchrist (1999) for a general discussion of the financial accelerator.

${ }^{9}$ While securitization markets provided funding in the U.S. mortgage lending expansion, concurrent real estate bubbles in Europe were bank financed (Wachter 2015).

${ }^{10}$ As a percentage of all MBS issued, these loans increased from less than 20 percent in 2002 to more than 50 percent in 2006, before collapsing entirely in 2007 (Levitin and Wachter 2012).

${ }^{11}$ See McCoy, Pavlov, and Wachter (2008) for a discussion of how deregulation resulted in the easing of lending terms. The literature that analyzes the impact of easier access to credit on house price increases includes Albanesi, DeGiorgi, and Nosal (2016), Anenberg et al. (2017), Adelino, Schoar, and Severino (2016), and Pavlov and Wachter (2011).

${ }^{12}$ The passage of state-level anti-predatory legislation appears to have also slowed the growth of nontraditional lending (Acolin, An, and Wachter 2018).

${ }^{13}$ As noted, RMBS and CDOs traded over the counter and infrequently, and were less a vehicle for trading than for funding savings vehicles with highly rated U.S. securities. CDS, sold by global financial entities, also traded over the counter. Bond guarantors, such as AIG, and the mono-lines, Ambac and MBIA, provided CDS, insuring investors in private-label RMBS and CDOs against default of the underlying securities (Financial Crisis Inquiry Commission 2011).

${ }^{14}$ Historically, managers of insurance firms appear to reserve for risk conservatively, as is explained by their incentive to stay in business (Kunreuther, Pauly, and McMorrow 2013).

${ }^{15}$ The structure of compensation incentives at these firms magnified the problem. A partnership model might have performed better by making management hold its wealth in the firm.

${ }^{16}$ For such a dynamic to occur, buyers of CDS from such institutions and their lenders need to be naive and blind to growing counterparty and default risk or need to assume bailouts will ensue with failure.

${ }^{17}$ See Richard (2011) for details on what information was available to Ackman and his decision to short CDS.

${ }^{18}$ More capital than would ever be necessary.

${ }^{19}$ Private mortgage insurance provides additional coverage.

${ }^{20}$ Fixed-rate mortgages involve investor retention of interest rate risk, while in an adjustable-rate mortgage, the interest rate risk is passed along to the borrower. See Green and Wachter (2005) for the role of the fixed-rate mortgage in the United States' housing finance system. 


\section{Notes (Continued)}

${ }^{21}$ The TBA market, with average daily trading volume nearly half that of U.S. Treasury securities, is of a liquidity and size that enable the efficient pricing of interest rate and prepayment risks (Kanojia and Grant 2016). The cost is borne by borrowers and is approximately equal to that of ten-year Treasury securities, augmented by the prepayment risk premium, which covers borrowers' option to prepay, absent on Treasury securities. See Kanojia and Grant for a discussion of the TBA market.

${ }^{22}$ For a discussion of the role of risk-based pricing in housing finance reform, see various chapters in Wachter and Tracy (2016).

${ }^{23}$ In addition, naïve investors in AAA tranches may have believed that they faced exposure only to interest rate and prepayment risk.

${ }^{24}$ See Oliner (2016) and Bai et al. (2016).

${ }^{25}$ The fee for the government's tail insurance should be priced through the cycle and therefore would not change because of a downturn in the housing market. The portion of the guarantee fee that would reprice would be the expected loss component. A major component of the fee is the required return on the guarantor's firm capital. The degree to which this reprices likely depends on whether one is relying on external or internal capital financing. Internal capital can be more long term and through the cycle. 


\section{REFERENCES}

Aastveit, K. A., and A. K. Anundsen. 2017. "Asymmetric Effects of Monetary Policy in Regional Housing Markets.” Norges Bank Working Paper, no. 25/2017, December.

Acolin, A., X. An, R. Bostic, and S. M. Wachter. 2017. "Lending Competition and Non-Traditional Mortgages." The Wharton School, University of Pennsylvania, Samuel Zell and Robert Lurie Real Estate Center, working paper no. 804.

Acolin, A., X. An, and S. M. Wachter. 2018. "Local Lending Competition, Regulation, and NonTraditional Mortgages.” Working paper, November.

Adelino, M., S. Schoar, and F. Severino. 2016. "Loan Originations and Defaults in the Mortgage Crisis: The Role of the Middle Class.” Review of Financial Studies 29, no. 7 (July): 1635-70.

Agarwal, S., J. Barrett, C. Cun, and M. De Nardi. 2010. "The Asset-Backed Securities Markets, the Crisis, and TALF." Economic Perspectives 34, no. 4: 101-15.

Albanesi, S., G. De Giorgi, and J. Nosal. 2017. "Credit Growth and the Financial Crisis: A New Narrative." NBER Working Paper no. 23740, August.

Anenberg, E., A. Hizmo, E. Kung, and R. Molloy. 2017. "Measuring Mortgage Credit Availability: A Frontier Estimation Approach.” Board of Governors of the Federal Reserve System, Finance and Economic Discussion Series Working Paper no. 2017-01.

Arentsen, E., D. C. Mauer, B. Rosenlund, H. H. Zhang, and F. Zhao. 2015. "Subprime Mortgage Defaults and Credit Default Swaps.” Journal of Finance 70, no. 2 (April): 689-731.

Bai, B., L. S. Goodman, and J. Zhu. 2016. "Overly Tight Credit Killed 1.1 Million Mortgages in 2015.” Urban Wire, Urban Institute.

Bank for International Settlements. 2013. "Statistical Release: OTC Derivatives Statistics at End-December 2012."

Bernanke, B. S., M. Gertler, and S. Gilchrist. 1999. “The Financial Accelerator in a Quantitative Business Cycle Framework.” In J. B. Taylor and M. Woodford, eds., Handbook of Macroeconomics. Vol. 1. Amsterdam: North-Holland Publishing Company.

Calem, P. S., R. Correa, and S. J. Lee. 2016. "Prudential Policies and Their Impact on Credit in the United States." Board of Governors of the Federal Reserve System, International Finance Discussion Papers, no. 1186, December.

Case, K. E., and R. J. Shiller. 1989. "The Efficiency of the Market for Single-Family Homes." AMERICAN ECONOMic Review 79, no. 1 (March): 125-37. 


\section{REFERENCES (Continued)}

Cordell, L., Y. Huang, and M. Williams. 2011. "Collateral Damage: Sizing and Assessing the Subprime CDO Crisis.” Federal Reserve Bank of Philadelphia Working Paper, no. 11-30.

Davidson, A. 2016. “Four Steps Forward: Streamline, Share Risk, Wrap, and Mutualize." Housing Finance Policy Center, Urban Institute.

Davidson, A., and R. Cooperstein. 2017. "Is There a Competitive Equilibrium for the GSEs?" Andrew Davidson and Company, working paper, September.

Davidson, A., A. Levin, and S. M. Wachter. 2014. "Mortgage Default Option Mispricing and Procyclicality.” In E. S. Belsky, C. E. Herbert, and J. H. Molinsky, eds., Homeownership Built to Last: Balancing Access, Affordability, and Risk after the Housing Crisis. Cambridge, Mass.: Brookings Institution Press/Harvard University Joint Center for Housing Studies.

De Marco, E., and M. Bright. 2016. “Toward a New Secondary Mortgage Market.” The Milken Institute, Center for Financial Markets.

Duca, J. V., L. Popoyan, and S. M. Wachter. Forthcoming. "Real Estate and the Great Crisis: Lessons for Macroprudential Policy." Contemporary Economic Policy.

Federal Housing Finance Agency. 2017. “Credit Transfer Progress Report.” https://www.fhfa.gov/aboutus/ reports/pages/credit-risk-transfer-progress-report.aspx.

Financial Crisis Inquiry Commission. 2011. "The Financial Crisis Inquiry Report.” https://fcic.law .stanford.edu/report/.

Frame, S. W., A. Fuster, J. Tracy, and J. Vickery. 2015. "The Rescue of Fannie Mae and Freddie Mac." Journal of Economic Perspectives 29, no. 2 (Spring): 25-52.

Gallin, J. 2008. “The Long-Run Relationship between House Prices and Rents.” Real Estate ECONOMics 36, no. 4 (Winter): 635-58.

Giglio, S. 2010. “CDS Spreads and Systemic Financial Risk.” Doctoral dissertation, Harvard University.

Glaeser, E. L., J. Gyourko, and A. Saiz. 2008. "Housing Supply and Housing Bubbles." Journal of Urban Economics 64, no. 2 (September): 198-217.

Green, R. K., and S. M. Wachter. 2005. “The American Mortgage in Historical and International Context." Journal of Economic Perspectives 19, no. 4 (Fall): 93-114.

Hendershott, P. H., and J. Slemrod. 1982. "Taxes and the User Cost of Capital for Owner-Occupied Housing." Real Estate Economics 10, no. 4 (December): 375-93. 


\section{REFERENCES (Continued)}

Herring, R., and S. M. Wachter. 2003. "Bubbles in Real Estate Markets." In W. C. Hunter, G. G. Kaufman, and M. Pomerleano, eds., Asset Price Bubbles: The Implications for Monetary, Regulatory, and International Policies. Cambridge, Mass.: MiT Press.

Herring, R. J., and S. M. Wachter. 1999. "Real Estate Booms and Banking Busts: An International Perspective." Group of Thirty, Occasional PaPers.

Jeske, K., D. Krueger, and K. Mitman. 2013. "Housing, Mortgage Bailout Guarantees, and the Macro Economy.” Journal of Monetary Economics 60, no. 8 (November): 917-35.

Kanojia, A., and M. Grant. 2016. “The TBA Market: Effects and Prerequisites.” In S. M. Wachter and J. Tracy, eds., Principles of Housing Finance Reform. Philadelphia: University of Pennsylvania Press.

Kunreuther, H. C., M. V. Pauly, and S. McMorrow. 2013. Insurance and Behavioral Economics: Improving Decisions in the Most Misunderstood Industry. Cambridge, U.K.: Cambridge University Press.

Lee, D., C. J. Mayer, and J. Tracy. 2012. “A New Look at Second Liens.” NBER Working Paper, no. 18269.

Levitin, A. J., D. Lin, and S. M. Wachter. Forthcoming. "Mortgage Risk Premiums during the Housing Bubble.” Journal of Real Estate Finance and Economics.

Levitin, A. J., and S. M. Wachter. 2012. "Explaining the Housing Bubble." Georgetown Law Journal 100, no. 4: 1177-1258.

—. 2015. "Second Liens and the Leverage Option." Vanderbilt Law Review 68, no. 5: 1243-94.

Loutskina, E., and P. E. Strahan. 2015. "Financial Integration, Housing, and Economic Volatility." Journal of Financial Economics 115, no. 1 (January): 25-41.

Markit. 2006. “ABX Indices: The New U.S. Asset-Backed Credit Default Swap Benchmark Indices.”

McCoy, P. A., A. D. Pavlov, and S. M. Wachter. 2008. "Systemic Risk through Securitization: The Result of Deregulation and Regulatory Failure." Connecticut Law Review 41: 1327.

McCoy, P. A., and S. M. Wachter. 2017. "Representations and Warranties: Why They Did Not Stop the Crisis." In L. A. Fennell and B. J. Keys, eds., Evidence and Innovation in Housing LaW AND Policy. Cambridge, U.K.: Cambridge University Press.

Mian, A., and S. Sufi. 2015. House of Debt: How They (and You) Caused the Great Recession, and How We Can Prevent It from Happening Again. Chicago: University of Chicago Press. 


\section{REFERENCES (CONTINUED)}

Moelis and Company, LLC. 2017. "Blueprint for Restoring Safety and Soundness to the GSEs."

Mortgage Bankers Association Task Force for a Future Secondary Mortgage Market. 2017. "GSE Reform Principles and Guardrails."

Mosser, P. C., J. Tracy, and J. Wright. 2016. “The Capital and Governance of a Mortgage Securitization Utility." Principles of Housing Finance Reform 32.

Oliner, S. 2016. “The Great Debate: Is Credit Loose?” American Enterprise Institute.

Parrott, J., L. Ranieri, G. Sperling, M. Zandi, and B. Zigas. 2016. “A More Promising Road to GSE Reform." Urban Institute.

Pavlov, A. D., E. Schwartz, and S. M. Wachter. 2017. "Price Discovery in the Credit Markets." University of Pennsylvania Wharton School Zell/Lurie Real Estate Center working paper, no. 805.

Pavlov, A. D., and S. M. Wachter. 2009. "Systemic Risk and Market Institutions." YaLe Journal on Regulation 26, no. 2: 445-55.

_ 2011. "Subprime Lending and Real Estate Prices." Real Estate Economics 38, no. 1: 1-17.

Pavlov, A. D., S. M. Wachter, and A. A. Zevelev. 2016. "Transparency in the Mortgage Market." Journal of Financial Services Research 49, no. 2-3: 265-80.

Poterba, J. M. 1984. “Tax Subsidies to Owner-Occupied Housing: An Asset-Market Approach.” Quarterly Journal of Economics 99, no. 4 (November): 729-52.

Richard, C. 2011. The Confidence Game: How Hedge Fund Manager Bill Ackman Called Wall Street's Bluff. Bloomberg Press.

Stanton, R., and N. Wallace. 2011. “The Bear's Lair: Index Credit Default Swaps and the Subprime Mortgage Crisis." Review of Financial Studies 24, no. 10 (October): 3250-80.

U. S. Court of Appeals for the Second District. 2016. Federal Housing Agency v. Nomura Holding America, Inc. 15-1872-cv(L).

Wachter, S. M. 2014. “The Market Structure of Securitization and the U.S. Housing Bubble.” National Institute Economic Review 230, no. 1 (November): 34-44.

— 2015. "The Housing and Credit Bubbles in the United States and Europe: A Comparison." Journal of Money, Credit, And Banking 47, no. S1 (March/April): 37-42. 


\section{REFERENCES (Continued)}

2016. "Credit Supply and Housing Prices in National and Local Markets." Public FinanCe

Review 44, no. 1 (January): 6-21.

2017. "Credit Risk Transfer and the Sustainability of Housing Finance."

https://ssrn.com/abstract=3086332.

Wachter, S. M., and J. S. Tracy, eds. 2016. Principles of Housing Finance Reform. Philadelphia:

University of Pennsylvania Press.

The Economic Policy Review is published by the Research and Statistics Group of the Federal Reserve Bank of New York. The views expressed are those of the individual authors and do not necessarily reflect the position of the Federal Reserve Bank of New York or the Federal Reserve System. Economic Policy Review articles may be reproduced for educational or training purposes, provided they are reprinted in full; include credit to the author(s), the publication, and the Bank; and include the publication's disclaimer.

(C) 2018 The Federal Reserve Bank of New York 